\title{
Kinetic and Spectroscopic Characterization of Cluster-Derived Supported Pt-Au Catalysts
}

\author{
Corina Mihut, ${ }^{*}$ Claude Descorme, $\nmid$ Daniel Duprez, $\dagger$ and Michael D. Amiridis*,1 \\ * Department of Chemical Engineering, College of Engineering and Information Technology, Swearingen Engineering \\ Center, University of South Carolina, Columbia, South Carolina 29208; and †Laboratoire de Catalyse en Chimie \\ Organique, UMR 6503 CNRS, Université de Poitiers, 40 avenue du Recteur Pineau, 86022 Poitiers, France
}

\begin{abstract}
Silica-supported bimetallic Pt-Au catalysts prepared via different synthetic routes have been investigated in terms of their structural properties, adsorption of $\mathrm{CO}$, and catalytic activity for the selective catalytic reduction of NO by propylene, the oxidation of propylene in the absence of $\mathrm{NO}$, and the ${ }^{16} \mathrm{O} /{ }^{18} \mathrm{O}$ homoexchange reaction. Catalysts prepared by incipient wetness impregnation from individual Pt and Au precursors exhibited characteristics very similar to those of monometallic Pt catalysts, indicating that in these cases the presence of Au did not affect the catalytic performance of Pt in any significant way. This behavior is consistent with a model in which the two metals remain segregated due to their miscibility gap, and only $\mathrm{Pt}$ participates in the adsorption of $\mathrm{CO}$ and the reactions under consideration. In contrast, catalysts prepared from a $\mathrm{Pt}_{2} \mathrm{Au}_{4}\left(\mathrm{C} \equiv \mathrm{C}^{\mathrm{t}} \mathrm{Bu}\right)_{8}$ organo-bimetallic cluster precursor exhibited different behavior both in terms of $\mathrm{CO}$ adsorption and their catalytic activity for the three reactions examined. The combination of the kinetic, spectroscopic, and structural characterization data suggests that in this case $\mathrm{Pt}$ and Au remain intimately mixed in the form of $\mathrm{Pt}-\mathrm{Au}$ bimetallic particles and that the presence of $\mathrm{Au}$ in these particles modifies the behavior of Pt. (c) 2002 Elsevier Science (USA)

Key Words: platinum; gold; synthesis; organometallic clusters; $\mathrm{CO}$ adsorption; $\mathrm{NO}_{\mathrm{x}}$ reduction; propylene oxidation; homoexchange reaction.
\end{abstract}

\section{INTRODUCTION}

Supported bimetallic $\mathrm{Pt}-\mathrm{Au}$ catalysts are primarily synthesized by impregnation, co-impregnation, and deposition-precipitation methods from individual $\mathrm{Pt}$ and $\mathrm{Au}$ salts. Phase separation of the two metals and inhomogeneous composition of the resulting bimetallic particles are common problems with this type of catalyst due to the large miscibility gap in the bulk phase between $\mathrm{Pt}$ and $\mathrm{Au}$ (i.e., between 18 and $97 \mathrm{wt} \% \mathrm{Pt}$ ) (1). Furthermore, the low melting point of $\mathrm{Au}$ and, therefore, the increased mobility of the Au atoms at high temperatures results in broad $\mathrm{Au}$ particle size distributions and difficulties

\footnotetext{
${ }^{1}$ To whom correspondence should be addressed. Fax: (803) 777-8265. E-mail: amiridis@engr.sc.edu.
}

in stabilizing $\mathrm{Au}$ in a small cluster form when these conventional preparation methods are used (2). Such segregation problems can be resolved, at least in principle, by the use of preformed bimetallic cluster precursors, frequently stabilized by organic ligands. Carbonyl-ligated clusters are preferred precursors for heterogeneous catalysts because of the advantage of the easy removal of the carbonyl groups by thermal treatment $(3,4)$. However, there are no known bimetallic $\mathrm{Pt}-\mathrm{Au}$ clusters exclusively ligated by carbonyl groups. In contrast, there are a few examples of phosphine stabilized bimetallic Au-containing clusters (i.e., $\left[\mathrm{Pt}\left(\mathrm{Au}\left(\mathrm{PPh}_{3}\right)_{8}\right]\left(\mathrm{NO}_{3}\right)_{2},\left[\mathrm{Pt}\left(\mathrm{PPh}_{3}\right)\left(\mathrm{AuPPh}_{3}\right)_{6}\right]\left(\mathrm{NO}_{3}\right)_{2}\right.$, and $\left.\left[\mathrm{Pt}\left(\mathrm{AuPPh}_{3}\right)_{2}\left(\mathrm{PPh}_{3}\right)_{2}\right]\left(\mathrm{NO}_{3}\right)_{2}\right)$ that have been immobilized and thermally activated on solid supports $(5,6)$. These clusters have high Au content, and the presence of phosphorous in the ligands represents a potential poison for several reactions. Recently, Chandler et al. (7-10) reported the preparation of a supported $\mathrm{Pt}-\mathrm{Au}$ catalyst from a cluster precursor that exclusively contains acetylide ligands and they concluded that true bimetallic $\mathrm{Pt}-\mathrm{Au}$ particles can be formed via this synthetic route. These ligands are easily removable at high temperatures.

In this paper, we followed the same synthetic approach and we compared the cluster-derived catalysts to catalysts having the same nominal composition, which were prepared by incipient wetness impregnation from hexachloroplatinic and tetrachloroauric acids. The structure of these catalysts was characterized by transmission electron microscopy (TEM), hydrogen chemisorption, and Fourier transform infrared spectroscopy of adsorbed ${ }^{12} \mathrm{CO} /{ }^{13} \mathrm{CO}$ mixtures. The chemical activity was probed by kinetic studies of the selective catalytic reduction of NO by propylene, the oxidation of propylene in the absence of NO, and the ${ }^{16} \mathrm{O} /{ }^{18} \mathrm{O}$ homoexchange reaction.

\section{EXPERIMENTAL METHODS}

\subsection{Catalyst Preparation}

Monometallic $\mathrm{Pt} / \mathrm{SiO}_{2}$ and $\mathrm{Au} / \mathrm{SiO}_{2}$ catalysts with $\mathrm{Pt}$ loadings of 1 or $0.15 \mathrm{wt} \%$ and Au loadings of 2 or $0.3 \%$ were 
prepared by incipient wetness impregnation of the $\mathrm{SiO}_{2}$ support (Davison Syloid 74; calcined overnight at $500^{\circ} \mathrm{C}$ prior to impregnation; BET surface area $300 \mathrm{~m}^{2} / \mathrm{g}$ ) with aqueous solutions of hexachloroplatinic $\left(\mathrm{H}_{2} \mathrm{PtCl}_{6} \cdot x \mathrm{H}_{2} \mathrm{O}\right.$, Aldrich) and tetrachloroauric acids $\left(\mathrm{HAuCl}_{4} \cdot 3 \mathrm{H}_{2} \mathrm{O}\right.$, Aldrich). Additionally, bimetallic catalysts containing $1 \mathrm{wt} \% \mathrm{Pt}-2 \mathrm{wt} \% \mathrm{Au}$ or $0.15 \mathrm{wt} \% \mathrm{Pt}-0.3 \mathrm{wt} \% \mathrm{Au}$ were prepared by co-impregnation (i.e., in this case both precursors were added in the same impregnation solution) using the same support material and precursors. Following impregnation, these catalysts were dried in vacuum for $2 \mathrm{~h}$ at $120^{\circ} \mathrm{C}$ and calcined in air for $5 \mathrm{~h}$ at $500^{\circ} \mathrm{C}$.

Cluster-derived catalysts were prepared via a wetimpregnation technique by adsorption of the organometallic $\mathrm{Pt}_{2} \mathrm{Au}_{4}\left(\mathrm{C} \equiv \mathrm{C}^{\mathrm{t}} \mathrm{Bu}\right)_{8}$ cluster precursor (11) from hexane solution onto the $\mathrm{SiO}_{2}$ support (Aldrich Davisil $\mathrm{SiO}_{2}$; calcined overnight at $500^{\circ} \mathrm{C}$ prior to impregnation; BET surface area $360 \mathrm{~m}^{2} / \mathrm{g}$ ) following the same procedure outlined in previous literature reports (7). The concentration of the cluster solution was adjusted so that the final metal loadings of the bimetallic catalysts obtained were approximately the same as those of the catalysts obtained by co-impregnation. Following impregnation, these catalysts were dried in vacuum for $2 \mathrm{~h}$ at $60^{\circ} \mathrm{C}$, oxidized at $300^{\circ} \mathrm{C}$ (temperature ramp $10^{\circ} \mathrm{C} / \mathrm{min}$ ) in a flowing $5 \% \mathrm{O}_{2} / \mathrm{He}$ mixture for $2 \mathrm{~h}$, and finally reduced at $200^{\circ} \mathrm{C}$ (same temperature ramp) for $1 \mathrm{~h}$ in a $5 \% \mathrm{H}_{2} / \mathrm{He}$ mixture. The different activation protocol was chosen in this case to assure mild removal of the acetylide ligands. The metal loadings of all catalysts used in this study were confirmed with elemental analysis via ICP (Galbraith Laboratories).

\subsection{Transmission Electron Microscopy Measurements}

In preparation for TEM imaging approximately $15 \mathrm{mg}$ of each sample were finely crushed and dispersed in $3 \mathrm{ml}$ deionized water by ultrasonification for $30 \mathrm{~min}$. A drop of this fine dispersion was deposited on a $\mathrm{Cu}$ grid and then dried at $40^{\circ} \mathrm{C}$ for $5-10$ min until the excess water was removed. Samples were then examined using a Hitachi 200-kV microscope. Digital images were recorded at magnifications of approximately 200,000. Particle size distributions were obtained by measuring 200 particles for each sample analyzed, using at least three different micrographs.

\subsection{Hydrogen Chemisorption Studies}

Pt dispersions were obtained via hydrogen chemisorption at room temperature (Autosorb AS-1 gas sorption system). Prior to these measurements, the samples were reduced in situ in flowing $\mathrm{H}_{2}$ at a temperature of $300^{\circ} \mathrm{C}$ for $3 \mathrm{~h}$, followed by evacuation at the same temperature for $2 \mathrm{~h}$. The samples were then cooled to $40^{\circ} \mathrm{C}$ and exposed to $\mathrm{H}_{2}$ at different pressures. Preselected amounts of $\mathrm{H}_{2}$ were added to the sample and the volumetric uptake of hydro- gen at different pressures was recorded as a function of the equilibrium pressure up to monolayer coverage. The monolayer coverage was determined based on the "extrapolation to zero pressure" method, which accounts for and subtracts the amount of physisorbed hydrogen. Measurements performed with the $2 \%$ Au sample and with the bare silica support indicated no $\mathrm{H}_{2}$ uptake in these cases. A stoichiometry of one adsorbed hydrogen atom per Pt surface atom was assumed in the calculations.

\subsection{Transmission Fourier-Transform Infrared Spectroscopy (FTIR) of Adsorbed CO}

Transmission FTIR spectra were collected in the singlebeam mode with a resolution of $2 \mathrm{~cm}^{-1}$ using a Nicolet 740 FTIR spectrometer equipped with an MCT-B detector. A 10-cm-long stainless steel IR cell, with $\mathrm{NaCl}$ windows cooled by flowing water, was used to collect in situ spectra. A heating element wrapped around the cell allowed spectra collection at elevated temperatures. The cell temperature was monitored by a thermocouple placed in close proximity to the catalyst sample. Reference spectra of the clean surfaces in $\mathrm{He}, 5 \% \mathrm{H}_{2} / \mathrm{He}$ or $5 \% \mathrm{O}_{2} / \mathrm{He}$ mixtures were collected at different temperatures as needed. Difference spectra between the samples and the corresponding reference are shown in this paper. Catalyst samples were selfsupported wafers with a diameter of $12 \mathrm{~mm}$ and a thickness of approximately $20 \mathrm{mg} / \mathrm{cm}^{2}$.

Two sets of experiments, each with different activation protocols, were conducted with each catalyst sample. In the first set (i.e., "oxidized" samples) the catalysts were exposed for $2 \mathrm{~h}$ in a flowing $5 \% \mathrm{O}_{2} / \mathrm{He}$ mixture at $300^{\circ} \mathrm{C}$ (cluster-derived samples) or $400^{\circ} \mathrm{C}$ (all other samples). In the second set (i.e., "reduced" samples) the catalysts were exposed for $2 \mathrm{~h}$ in a flowing $5 \% \mathrm{H}_{2} / \mathrm{He}$ mixture at $300^{\circ} \mathrm{C}$. Following these pretreatments the samples were cooled in either $\mathrm{O}_{2} / \mathrm{He}$ or $\mathrm{H}_{2} / \mathrm{He}$ mixtures to $100^{\circ} \mathrm{C}$, flushed with $\mathrm{He}$, and cooled in He to room temperature. At room temperature a flowing $\mathrm{CO} / \mathrm{He}$ mixture ( $\mathrm{CO}$ concentrations of $3000 \mathrm{ppm}$ and $3 \%$ ) was introduced to the cell and spectra were collected at different time intervals until steady state was reached (usually after $20 \mathrm{~min}$ ). Helium was then purged through the cell and spectra were collected at different time intervals and elevated temperatures until the entire amount of adsorbed $\mathrm{CO}$ was removed from the surface.

Experiments were also conducted at room temperature with mixtures of ${ }^{12} \mathrm{CO}$ and ${ }^{13} \mathrm{CO}$ at a total flow rate of $5 \mathrm{ml} / \mathrm{min}$ and at different ratios $\left(35 \%{ }^{12} \mathrm{CO}-65 \%{ }^{13} \mathrm{CO}\right.$, $\left.50 \%{ }^{12} \mathrm{CO}-50 \%{ }^{13} \mathrm{CO}, 65 \%{ }^{12} \mathrm{CO}-35 \%{ }^{13} \mathrm{CO}\right)$. The $\mathrm{CO}$ in this case was diluted in $95 \mathrm{ml} / \mathrm{min}$ of $\mathrm{He}$ and was flowed over the catalyst pellet for $30 \mathrm{~min}$ to allow equilibration of the surface. The gas-phase spectra of the ${ }^{12} \mathrm{CO}-{ }^{13} \mathrm{CO}$ mixtures were subtracted from the spectra shown in this paper. 


\subsection{Activity Measurements}

2.5.1. ${ }^{16} \mathrm{O} / 18 \mathrm{O}$ homoexchange reaction. Activity measurements for the ${ }^{16} \mathrm{O} /{ }^{18} \mathrm{O}$ homoexchange reaction were carried out on 20-mg samples in a batch recirculation reactor described in detail elsewhere (12). Prior to reaction, the samples were oxidized at $400^{\circ} \mathrm{C}\left(10^{\circ} \mathrm{C} / \mathrm{min}\right)$ in pure ${ }^{16} \mathrm{O}_{2}$ for $15 \mathrm{~min}$, outgassed under vacuum at $400^{\circ} \mathrm{C}$ for $15 \mathrm{~min}$, reduced at the same temperature for $15 \mathrm{~min}$ in pure $\mathrm{H}_{2}$, and finally outgassed again at $400^{\circ} \mathrm{C}$ under vacuum for $30 \mathrm{~min}$. Following this pretreatment the samples were cooled to the reaction temperature and an equimolar mixture of ${ }^{18} \mathrm{O}_{2}$ and ${ }^{16} \mathrm{O}_{2}$ ( $P_{\text {total }}=50$ mbar $)$ was introduced to the reactor. The progress of the reaction was followed by mass spectrometry. Masses $36\left({ }^{18} \mathrm{O}_{2}\right), 34\left({ }^{18} \mathrm{O}^{16} \mathrm{O}\right), 32\left({ }^{16} \mathrm{O}_{2}\right), 28\left(\mathrm{~N}_{2}\right)$, and $18\left(\mathrm{H}_{2} \mathrm{O}\right)$ were monitored continuously. (Masses 28 and 18 were monitored to assure that no leak occured into the reactor.)

The homoexchange reaction rate $\left(V_{\mathrm{q}}\right)$, expressed in oxygen atoms exchanged per hour per surface Pt site was calculated as follows:

$$
V_{\mathrm{q}}=\frac{2 \cdot M W_{\mathrm{Pt}}}{m \cdot x(\mathrm{wt}) \cdot D \cdot R} \cdot\left(\frac{V_{\mathrm{r}}}{T_{\mathrm{r}}}+\frac{V_{\mathrm{c}}}{T_{\mathrm{c}}}\right) \cdot\left(\frac{d P_{18}^{\mathrm{o}} \mathrm{O}^{16} \mathrm{O}}{d t}\right)
$$

where $M W_{\mathrm{Pt}}$ is the atomic weight of $\mathrm{Pt}(\mathrm{g} / \mathrm{mol}), m$ is the sample mass $(\mathrm{g}), x(\mathrm{wt})$ is the $\mathrm{Pt}$ loading of the sample, $D$ is the $\mathrm{Pt}$ dispersion, $R$ is the ideal gas constant $\left(8.314 \mathrm{~J} \mathrm{~K}^{-1} \mathrm{~mol}^{-1}\right)$, $V_{\mathrm{r}}$ and $V_{\mathrm{c}}$ are the reactor and loop volumes $\left(\mathrm{cm}^{3}\right), T_{\mathrm{r}}$ and $T_{\mathrm{c}}$ are the reactor and loop temperatures $(\mathrm{K})$, and $\frac{d P_{18}^{\mathrm{O}} \mathrm{O}_{\mathrm{O}} \mathrm{O}}{d t}$ is the initial rate of formation of ${ }^{18} \mathrm{O}^{16} \mathrm{O}$.

2.5.2. Selective catalytic reduction of $\mathrm{NO}$ by $\mathrm{C}_{3} \mathrm{H}_{6}$. Steady-state activity measurements of the selective catalytic reduction of $\mathrm{NO}$ by $\mathrm{C}_{3} \mathrm{H}_{6}$ (HC-SCR) were conducted in a quartz single-pass fixed-bed flow reactor. Prior to the activity measurements all catalyst samples were oxidized in situ at $500^{\circ} \mathrm{C}$ in a $5 \% \mathrm{O}_{2} / \mathrm{He}$ mixture for $2 \mathrm{~h}$. Certified mixtures of $1.00 \% \mathrm{NO}$ in $\mathrm{He}, 1.03 \% \mathrm{C}_{3} \mathrm{H}_{6}$ in $\mathrm{He}, 9.80 \%$ $\mathrm{O}_{2}$ in $\mathrm{He}$, and a $99.999 \% \mathrm{He}$ carrier gas, provided and certified by National Specialty Gases, were used to prepare the reacting gas mixture. Typical gas concentrations used were $1000 \mathrm{ppm}_{\mathrm{v}} \mathrm{NO}, 1000 \mathrm{ppm}_{\mathrm{v}} \mathrm{C}_{3} \mathrm{H}_{6}, 1 \% \mathrm{O}_{2}$, and balance helium. Inlet and outlet gas streams were analyzed by the use of a gas chromatograph (Hewlett-Packard 5890) equipped with a thermal conductivity detector and three chromatographic columns: Molecular Sieve 5A (for the analysis of $\mathrm{N}_{2}$ ), Porapak $\mathrm{Q}$ (for the analysis of $\mathrm{N}_{2} \mathrm{O}$ and $\mathrm{CO}_{2}$ ), and Graphpac GC (for the analysis of $\mathrm{C}_{3} \mathrm{H}_{6}$ ) connected in parallel. The reaction temperature was varied between 200 and $500^{\circ} \mathrm{C}$ and was monitored by a thermocouple placed in the catalyst bed.

Measurements with samples containing $1 \% \mathrm{Pt}$ and/or $2 \%$ Au used $100 \mathrm{mg}$ of the catalyst in the form of $60 / 80$ mesh particles. The total volumetric flow rate of the reactant mix- ture was held at $200 \mathrm{~cm}^{3} / \mathrm{min}\left(1 \mathrm{~atm}, 25^{\circ} \mathrm{C}\right)$ with a corresponding gas hourly space velocity (GHSV) of $120,000 \mathrm{~cm}^{3} /$ $\mathrm{gm} / \mathrm{hr}$. Measurements with samples containing $0.15 \mathrm{wt} \%$ $\mathrm{Pt}$ and/or $0.3 \mathrm{wt} \% \mathrm{Au}$ used $300 \mathrm{mg}$ of catalyst and a total flow rate of $100 \mathrm{~cm}^{3} / \mathrm{min}$, so that the overall space velocity was decreased proportionally to the Pt loading and similar overall NO conversions were obtained with both sets of samples. The percentage NO reduction was calculated from the amounts of $\mathrm{N}_{2}$ and $\mathrm{N}_{2} \mathrm{O}$ formed, while the selectivity toward $\mathrm{N}_{2}$ and $\mathrm{N}_{2} \mathrm{O}$ was defined as the amount of $\mathrm{N}_{2}$ formed divided by the total $\mathrm{N}_{2}$ and $\mathrm{N}_{2} \mathrm{O}$ formed. The only reaction products observed from the oxidation of $\mathrm{C}_{3} \mathrm{H}_{6}$ were $\mathrm{CO}_{2}$ and $\mathrm{H}_{2} \mathrm{O}$, and the carbon mass balance was closed within $\pm 5 \%$.

\section{RESULTS}

\subsection{TEM Measurements and $\mathrm{H}_{2}$ Chemisorption}

Number-average metal particle sizes, as well as the results of the hydrogen uptake measurements for different fresh and "used" (i.e., exposed to HC-SCR conditions) samples are summarized in Table 1. Furthermore, metal particle size distributions for the 1Pt and the 1Pt-2Au samples prepared by impregnation, and the cluster-derived $0.5 \mathrm{Pt}_{2} \mathrm{Au}_{4}$ sample are shown in Fig. 1. The results indicate similar metal particle size averages for the monometallic $1 \mathrm{Pt}$ and the coimpregnated $1 \mathrm{Pt}-2 \mathrm{Au}$ samples. In contrast, a smaller average metal particle size (3.4 versus $4.6 \mathrm{~nm}$ ) and a more narrow distribution are observed with the cluster-derived $0.5 \mathrm{Pt}_{2} \mathrm{Au}_{4}$ sample. Evidence that mild sintering is taking place as a result of exposure to HC-SCR reaction conditions becomes apparent when the average metal particle sizes of the used samples are compared to the corresponding averages for the fresh samples (Table 1). The observed changes, however, are similar for all three samples and indicate that the cluster-derived $0.5 \mathrm{Pt}_{2} \mathrm{Au}_{4}$ catalyst maintains a smaller average metal particle size than the other two samples during exposure to temperatures up to $500^{\circ} \mathrm{C}$ in the presence of $\mathrm{O}_{2}$ (i.e., HC-SCR conditions). Finally, Pt dispersions estimated based on hydrogen uptake measurements (Table 1) are consistent with the TEM measurements, indicating a higher uptake for the cluster-derived $0.5 \mathrm{Pt}_{2} \mathrm{Au}_{4}$ sample and mild sintering for the used samples.

\section{TABLE 1}

Properties of Different Catalysts Used in this Study

\begin{tabular}{|c|c|c|c|c|c|c|}
\hline \multirow[b]{2}{*}{ Catalyst } & \multicolumn{2}{|c|}{ Loading (\%) } & \multicolumn{2}{|c|}{$\begin{array}{c}\text { Average metal } \\
\text { particle size }(\mathrm{nm})\end{array}$} & \multicolumn{2}{|c|}{$\begin{array}{l}\text { Hydrogen uptake } \\
\left(\text { moles } \mathrm{H}_{2} / \text { mole } \mathrm{Pt}\right)\end{array}$} \\
\hline & $\mathrm{Pt}$ & $\mathrm{Au}$ & Fresh & Used & Fresh & Used \\
\hline $1 \mathrm{Pt}$ & 1.04 & - & 4.7 & 5.3 & 0.158 & 0.108 \\
\hline $1 \mathrm{Pt}-2 \mathrm{Au}$ & 0.79 & 1.81 & 4.6 & 5.6 & 0.153 & 0.101 \\
\hline $0.5 \mathrm{Pt}_{2} \mathrm{Au}_{4}$ & 0.77 & 1.54 & 3.4 & 4.0 & 0.223 & 0.2 \\
\hline
\end{tabular}




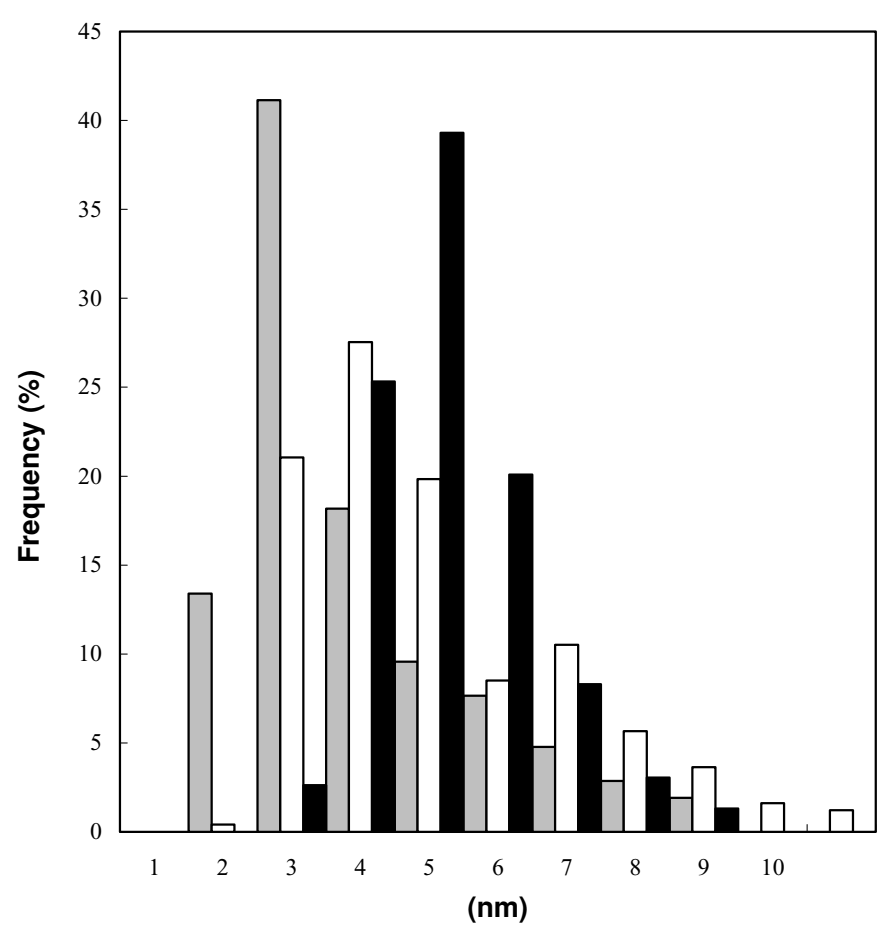

FIG. 1. TEM histograms of the fresh co-impregnated and clusterderived catalysts $\left(\square, 0.5 \mathrm{Pt}_{2} \mathrm{Au}_{4}\right.$ fresh sample; $\mathbf{\square}, 1 \mathrm{Pt}$ fresh sample; $\square$, 1Pt-2Au fresh sample).

\subsection{FTIR Spectroscopy of Adsorbed CO}

FTIR studies of adsorbed CO were performed on both reduced and oxidized samples, in an attempt to understand the effect of the Au presence on the structure and properties of Pt. Spectra collected at room temperature on reduced catalyst samples following exposure to $3.3 \mathrm{kPa}$ of $\mathrm{CO}$ are shown in Fig. 2. A strong peak at $2070 \mathrm{~cm}^{-1}$ (Fig. 2, spectrum b) is observed in the spectrum of the monometallic $1 \mathrm{Pt}$ sample, in agreement with literature reports (13). This peak was assigned to $\mathrm{CO}$ linearly adsorbed on fully reduced $\mathrm{Pt}$ sites. The addition of $\mathrm{Au}$ via co-impregnation, as in the 1Pt-2Au sample, did not affect the $\mathrm{CO}$ adsorption (Fig. 2, spectrum c), consistent with previous literature reports $(7,13,14)$. Furthermore, no peak assignable to $\mathrm{CO}$ adsorbed on $\mathrm{Au}$ was observed for the $2 \mathrm{Au}$ sample (Fig. 2, spectrum d).

In contrast, some significant differences can be noticed in the spectra of the $0.5 \mathrm{Pt}_{2} \mathrm{Au}_{4}$ catalyst (Fig. 2, spectrum a) in agreement with similar results reported by Chandler et al. (7) for the adsorption of $\mathrm{CO}$ on cluster-derived $\mathrm{Pt}-\mathrm{Au}$ catalysts. In particular, a red shift from 2070 to $2064 \mathrm{~cm}^{-1}$ is observed in the position of the peak assigned to CO linearly bound to $\mathrm{Pt}$, and a new peak is observed at $2117 \mathrm{~cm}^{-1}$ assigned to $\mathrm{CO}$ bound to finely dispersed $\mathrm{Au}$. Furthermore, a weak shoulder and substantial asymmetric tailing in the low-frequency region can be observed in the CO-Pt peak of Fig. 2, spectrum a. Similarly, substantial asymmetric tail- ing in the high-frequency region can be observed in the $\mathrm{CO}-\mathrm{Au}$ peak of the same spectrum. These features are more pronounced than the corresponding asymmetric tailing observed in the spectra of the monometallic $\mathrm{Pt} / \mathrm{SiO}_{2}$ and the co-impregnated $\mathrm{Pt}-\mathrm{Au} / \mathrm{SiO}_{2}$ samples (Spectra $2 \mathrm{c}$ and $2 \mathrm{~b}$ ) and suggest that the cluster-derived catalyst contains a broader distribution of $\mathrm{CO}$ adsorption sites of different adsorption strengths. Indeed, attempts to deconvolute these peaks using different software packages, yielded results indicating that a number of smaller intensity peaks is needed in order to fit the asymmetric tailing shown in Fig. 2, spectrum a.

Purging the $\mathrm{CO}$-saturated $0.5 \mathrm{Pt}_{2} \mathrm{Au}_{4}$ sample with an inert atmosphere results in the complete removal of the Aubound $\mathrm{CO}$ (Fig. 3) after approximately $40 \mathrm{~min}$. At the same time, the peak at $2064 \mathrm{~cm}^{-1}$ assigned to Pt-bound CO decreases slightly in intensity at room temperature and is completely eliminated at temperatures around $150^{\circ} \mathrm{C}$. These results are in agreement with results from previous studies on supported $\mathrm{Au}$ and $\mathrm{Pt}-\mathrm{Au}$ catalysts, where outgassing at room temperature completely depletes the band associated with $\mathrm{CO}$ bound to $\mathrm{Au}(15-17)$.

Spectra of adsorbed CO on a "used" catalyst following a reduction treatment at $300^{\circ} \mathrm{C}$ are shown in Fig. 4. Even after exposure to reaction conditions the two distinctive IR features (namely, the red shift in the CO-Pt peak and the appearance of the $\mathrm{CO}-\mathrm{Au}$ peak) are still present. This result is consistent with the kinetic results, indicating no catalyst deactivation or change in the selectivity toward $\mathrm{N}_{2}$ even after prolonged exposure of the $0.5 \mathrm{Pt}_{2} \mathrm{Au}_{4}$ catalyst to the reaction conditions. Similar to the fresh

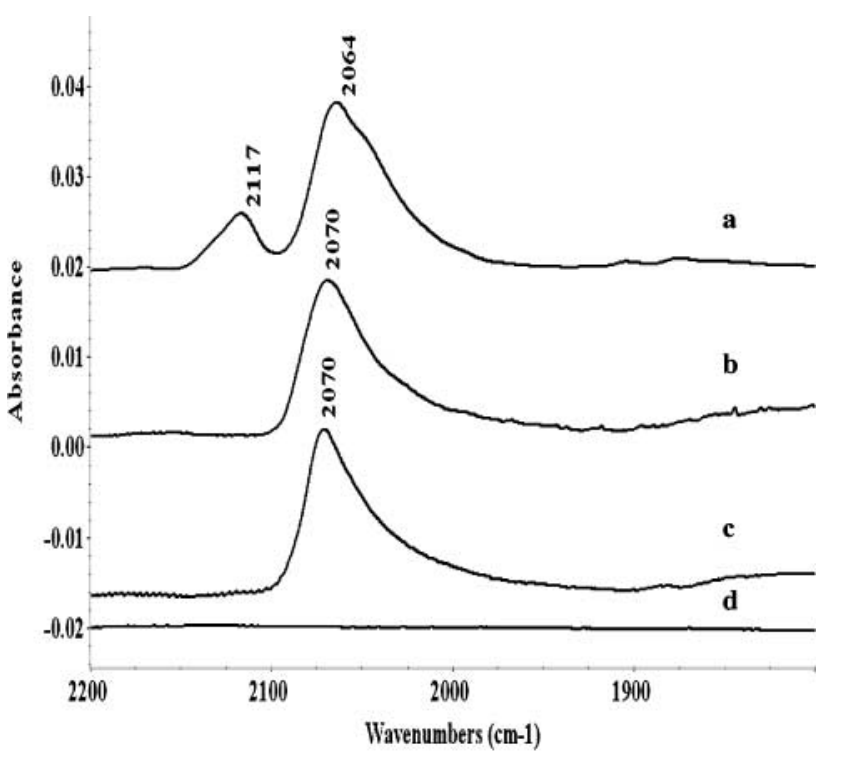

FIG. 2. IR spectra of adsorbed $\mathrm{CO}$ at room temperature $\left(30^{\circ} \mathrm{C}\right)$ on reduced $\mathrm{SiO}_{2}$-supported $\mathrm{Pt}$ and $\mathrm{Pt}-\mathrm{Au}$ catalysts. Spectra were collected immediately following the removal of gas-phase $\mathrm{CO}$ : (a) $0.5 \mathrm{Pt}_{2} \mathrm{Au}_{4}$, (b) $1 \mathrm{Pt}$, (c) $1 \mathrm{Pt}-2 \mathrm{Au},(\mathrm{d}) 2 \mathrm{Au}$. 


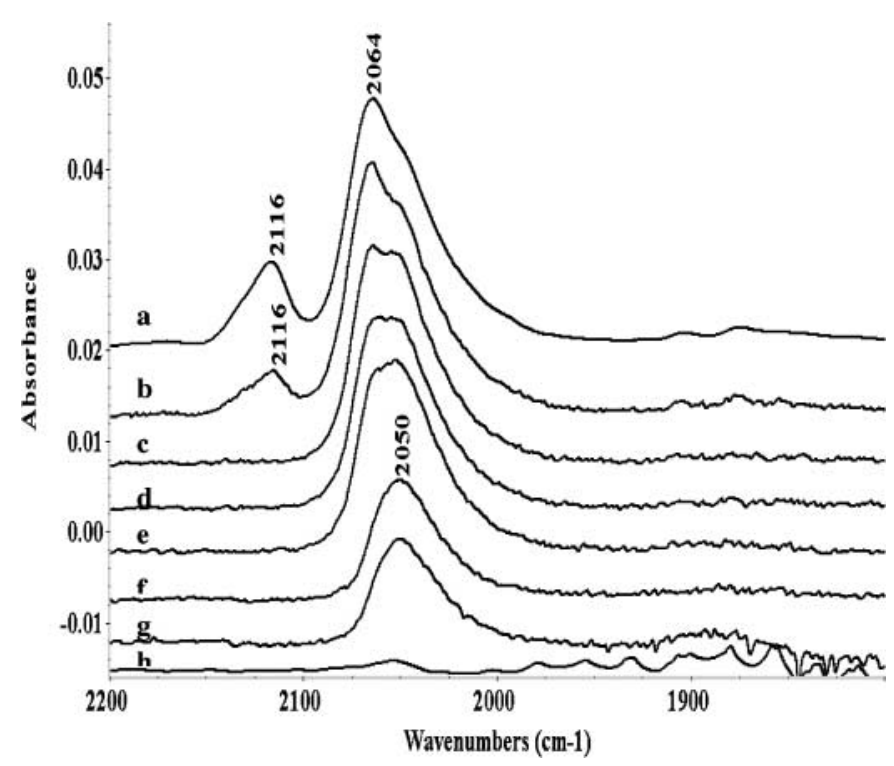

FIG. 3. IR spectra of adsorbed $\mathrm{CO}$ on reduced $0.5 \mathrm{Pt}_{2} \mathrm{Au}_{4}$ catalyst. Spectra were collected following exposure to $0.3 \mathrm{kPa} \mathrm{CO}$ for $1 \mathrm{~h}$ at room temperature (RT) and He purge: (a) immediately following CO gas-phase removal at RT, (b) for $5 \mathrm{~min}$ at $\mathrm{RT}$, (c) for $70 \mathrm{~min}$ at $\mathrm{RT}$, (d) for $230 \mathrm{~min}$ at $\mathrm{RT}$, (e) for $10 \mathrm{~min}$ at $50^{\circ} \mathrm{C}$, (f) for $10 \mathrm{~min}$ at $75^{\circ} \mathrm{C}$, (g) for $10 \mathrm{~min}$ at $100^{\circ} \mathrm{C}$, and (h) for $10 \mathrm{~min}$ at $150^{\circ} \mathrm{C}$.

cluster-derived sample, purging with $\mathrm{He}$ at room temperature quickly removed the $\mathrm{CO}-\mathrm{Au}$ peak, while an elevated temperature was required for the elimination of the $\mathrm{CO}-\mathrm{Pt}$ peak.

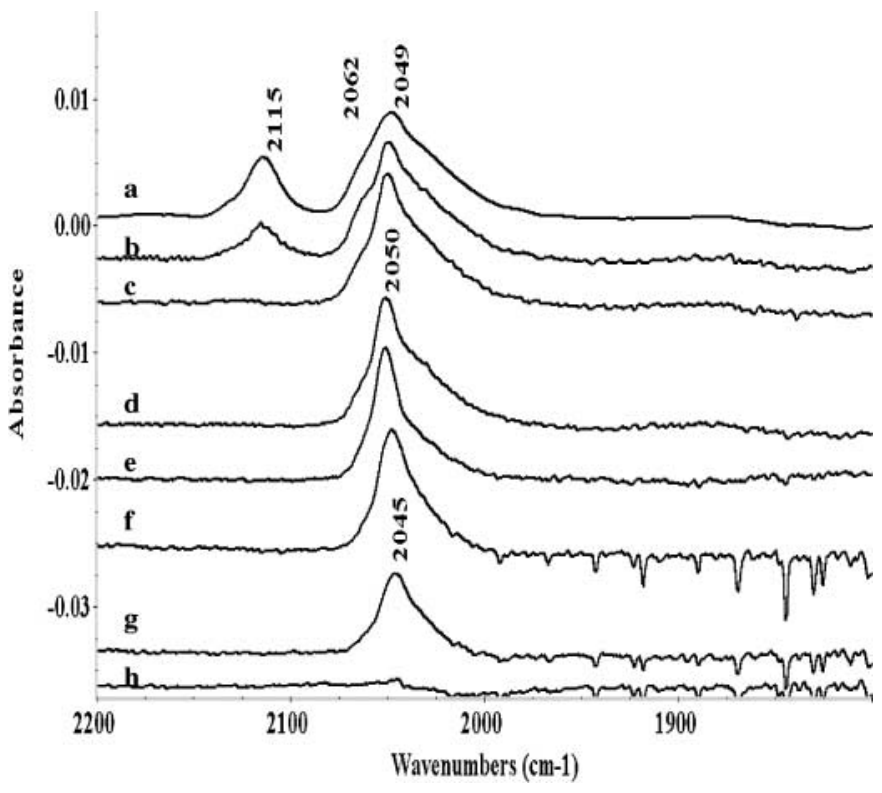

FIG. 4. IR spectra of adsorbed $\mathrm{CO}$ on used reduced $0.5 \mathrm{Pt}_{2} \mathrm{Au}_{4}$ catalyst. Spectra were collected immediately following the removal of the gasphase CO: (a) $20 \mathrm{~min}$ at RT, (b) $25 \mathrm{~min}$ at RT, (c) $1 \mathrm{~h}$ at RT, (d) $20 \mathrm{~min}$ at $50^{\circ} \mathrm{C}$, (e) $20 \mathrm{~min}$ at $80^{\circ} \mathrm{C}$, (f) $20 \mathrm{~min}$ at $125^{\circ} \mathrm{C},(\mathrm{g}) 20 \mathrm{~min}$ at $150^{\circ} \mathrm{C}$, (h) $20 \mathrm{~min}$ at $190^{\circ} \mathrm{C}$.

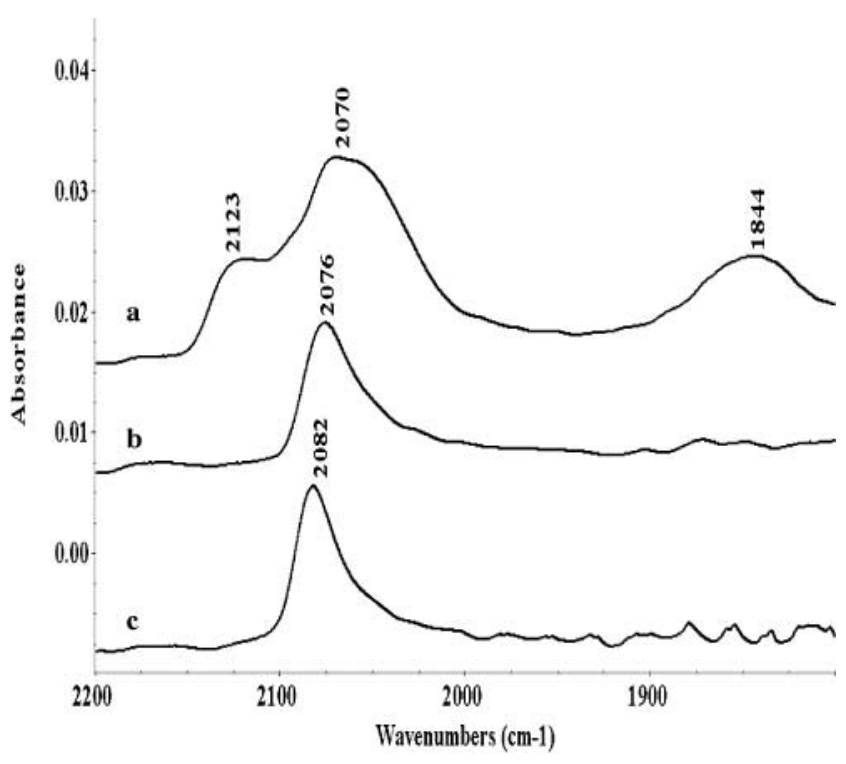

FIG. 5. IR spectra of adsorbed $\mathrm{CO}$ at $\mathrm{RT}\left(30^{\circ} \mathrm{C}\right)$ over $\mathrm{SiO}_{2}$-supported oxidized Pt and Pt-Au catalysts. Spectra were collected immediately following removal of the gas-phase $\mathrm{CO}$ : (a) $0.5 \mathrm{Pt}_{2} \mathrm{Au}_{4}$, (b) $1 \mathrm{Pt}$, (c) $1 \mathrm{Pt}-2 \mathrm{Au}$.

Similar results to the ones obtained with the reduced samples were also observed with samples pretreated in oxygen. In this case, however, the $\mathrm{CO}$ stretching frequencies occur consistently at higher wave numbers. This could be due to either a compression of the $\mathrm{CO}$ layer caused by co-adsorbed oxygen, which predictably leads to higher frequencies than the ones obtained on reduced surfaces, or to an electronic effect associated with a weakening of the surface $\mathrm{CO}$ bond under these conditions (18). Spectra of the oxidized samples after exposure to $\mathrm{CO}$ at room temperature are shown in Fig. 5. Once again, a red shift of the $\mathrm{Pt}-\mathrm{CO}$ peak and a new peak at $2123 \mathrm{~cm}^{-1}$ characteristic of Au-bound $\mathrm{CO}$ are evident in the spectrum of the $0.5 \mathrm{Pt}_{2} \mathrm{Au}_{4}$ sample (Fig. 5, spectrum a). Furthermore, a new peak is identified in Fig. 5 (spectrum a) at $1844 \mathrm{~cm}^{-1}$ and can be assigned to bridge-bonded $\mathrm{CO}$ on $\mathrm{Pt}(19,20)$.

FTIR studies of adsorbed $\mathrm{CO}$ were also conducted with the prereduced $1 \mathrm{Pt}, 1 \mathrm{Pt}-2 \mathrm{Au}$, and $0.5 \mathrm{Pt}_{2} \mathrm{Au}_{4}$ samples at elevated temperatures. Results of these studies are shown in Figs. 6 (for $1 \mathrm{Pt}$ ) and 7 (for $0.5 \mathrm{Pt}_{2} \mathrm{Au}_{4}$ ). The results obtained for the $1 \mathrm{Pt}-2 \mathrm{Au}$ are identical to those obtained with $1 \mathrm{Pt}$ and have not been included for brevity. In all cases, when the temperature was increased in the presence of gas-phase $\mathrm{CO}$ while the surface was allowed to equilibrate, the vibration frequency of adsorbed $\mathrm{CO}$ was noticeably decreased. It was also noticed that total $\mathrm{CO}$ desorption from $\mathrm{Pt}$ sites in the cluster-derived $0.5 \mathrm{Pt}_{2} \mathrm{Au}_{4}$ catalyst occurs at higher temperatures than from the monometallic $1 \mathrm{Pt}$ sample. This suggests that on the average the CO-Pt bond is stronger in the cluster-derived catalyst (i.e., the fraction of lower coordination Pt sites is higher in this sample). This result is consistent with the substantial asymmetric tailing in the 


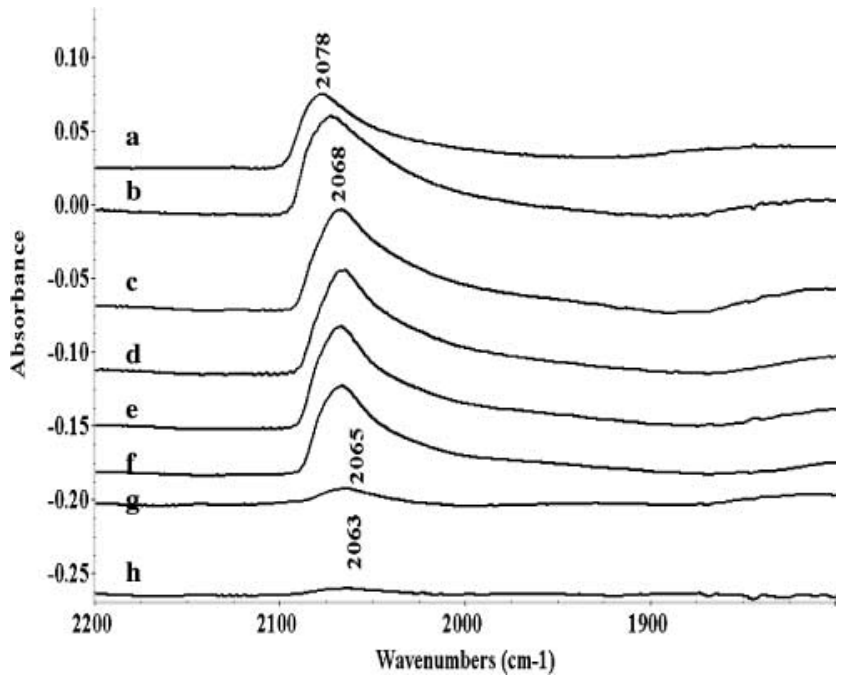

FIG. 6. FTIR spectra of adsorbed $\mathrm{CO}$ on reduced $1 \mathrm{Pt}$ collected in the presence of gas-phase $\mathrm{CO}$ at different temperatures: (a) RT, (b) $70^{\circ} \mathrm{C}$, (c) $105^{\circ} \mathrm{C}$, (d) $145^{\circ} \mathrm{C}$, (e) $175^{\circ} \mathrm{C}$, (f) $204^{\circ} \mathrm{C}$, (g) $220^{\circ} \mathrm{C}$, and (h) $245^{\circ} \mathrm{C}$.

low-frequency region of the CO-Pt peak, which was discussed in a previous paragraph. Furthermore, the results of Figs. 6 and 7 suggest that the observed red shift at room temperature (i.e., full coverage) between $\mathrm{CO}$ adsorbed on $\mathrm{Pt}$ sites on $1 \mathrm{Pt}$ (or $1 \mathrm{Pt}-2 \mathrm{Au}$ ) and $0.5 \mathrm{Pt}_{2} \mathrm{Au}_{4}$ may be related to differences in the singleton frequency of the adsorbed $\mathrm{CO}$ on these samples, since at the corresponding highest temperatures (i.e., lowest $\mathrm{CO}$ coverage) this red shift is further enhanced (from $2063 \mathrm{~cm}^{-1}$ for $1 \mathrm{Pt}$ and $1 \mathrm{Pt}-2 \mathrm{Au}$ to $2049 \mathrm{~cm}^{-1}$ for $\left.0.5 \mathrm{Pt}_{2} \mathrm{Au}_{4}\right)$. Finally, no significant shift was observed at elevated temperatures with the $\mathrm{CO}-\mathrm{Au}$ band,

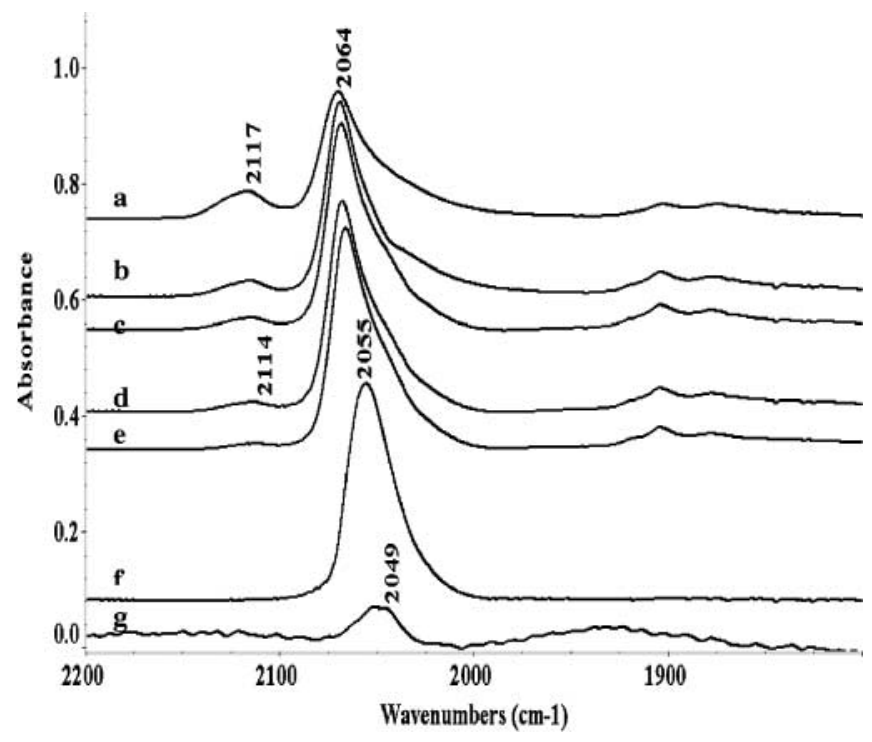

FIG. 7. FTIR spectra of adsorbed $\mathrm{CO}$ on reduced $0.5 \mathrm{Pt}_{2} \mathrm{Au}_{4}$ collected in the presence of gas-phase $\mathrm{CO}$ at different temperatures: (a) RT, (b) $60^{\circ} \mathrm{C}$, (c) $70^{\circ} \mathrm{C}$, (d) $85^{\circ} \mathrm{C}$, (e) $110^{\circ} \mathrm{C}$, (f) $249^{\circ} \mathrm{C}$, and (g) $275^{\circ} \mathrm{C}$. indicating minimal coverage effects in this case. The clear difference in the magnitude of the shifts of the $\mathrm{CO}-\mathrm{Au}$ and $\mathrm{CO}-\mathrm{Pt}$ bands is another indication that the two bands are uncoupled and belong to different species. It is worth noting that previous room-temperature studies of the adsorption of $\mathrm{CO}$ on monometallic $\mathrm{Au} / \mathrm{SiO}_{2}$ catalysts indicate a blue shift with decreasing CO pressure $(15,21-23)$.

These results appear to suggest that the role of $\mathrm{Au}$ in the cluster-derived catalyst is beyond that of simply breaking up large Pt ensembles, and that Au may be electronically modifying the properties of Pt. However, due to the possibility of islands of $\mathrm{CO}$ formation even at low surface coverages (24), in which situation the dipole-dipole coupling is not completely eliminated, this hypothesis was further verified by collecting spectra of adsorbed ${ }^{12} \mathrm{CO} /{ }^{13} \mathrm{CO}$ mixtures at different ratios between the two isotopes. The dilution of one isotope in the other and the subsequent extrapolation of the observed frequencies to zero coverage yields another estimate of the singleton frequency. The frequency of ${ }^{13} \mathrm{CO}-$ $\mathrm{Pt}$ was used in these calculations, because of interference between the frequency of ${ }^{12} \mathrm{CO}-\mathrm{Pt}$ and that of ${ }^{13} \mathrm{CO}-\mathrm{Au}$ (at approximately $2064 \mathrm{~cm}^{-1}$ ) in the $0.5 \mathrm{Pt}_{2} \mathrm{Au}_{4}$ sample.

The IR spectra collected with different mixtures of adsorbed ${ }^{12} \mathrm{CO} /{ }^{13} \mathrm{CO}$ on pre-reduced $1 \mathrm{Pt}$ are shown in Fig. 8. The intensities associated with the two bands do not necessarily correspond to the ratio of the two isotopes in the mixture, since a transfer of intensity from one band to the other is possible, as was discussed previously by Toolenaar et al. (25) for $\mathrm{Pt}-\mathrm{Cu}$ alloys. For the same reason, spectra collection at molar fractions above $4: 1$ or below 1:4 was virtually impossible. The spectra were deconvoluted using curve-fitting software packages, and peak

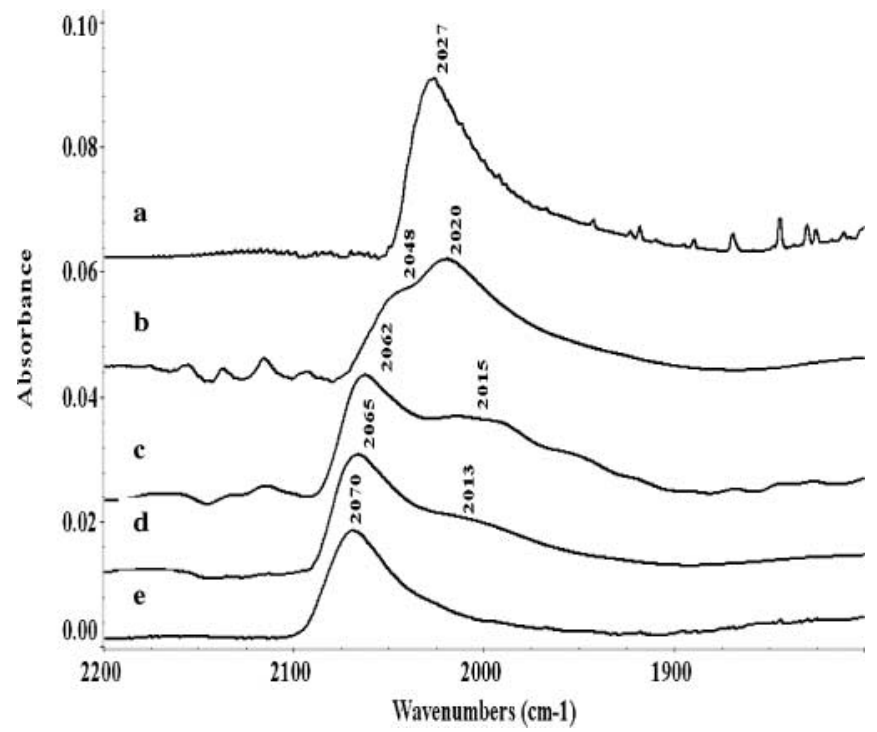

FIG. 8. RT spectra of mixtures of ${ }^{12} \mathrm{CO} /{ }^{13} \mathrm{CO}$ adsorbed on prereduced 1Pt: (a) $100 \%{ }^{13} \mathrm{CO}$, (b) $35 \%{ }^{12} \mathrm{CO} / 65 \%{ }^{13} \mathrm{CO}$, (c) $50 \%{ }^{12} \mathrm{CO} / 50 \%$ ${ }^{13} \mathrm{CO}$, (d) $65 \%{ }^{12} \mathrm{CO} / 35 \%{ }^{13} \mathrm{CO}$, and (e) $100 \%{ }^{12} \mathrm{CO}$. 


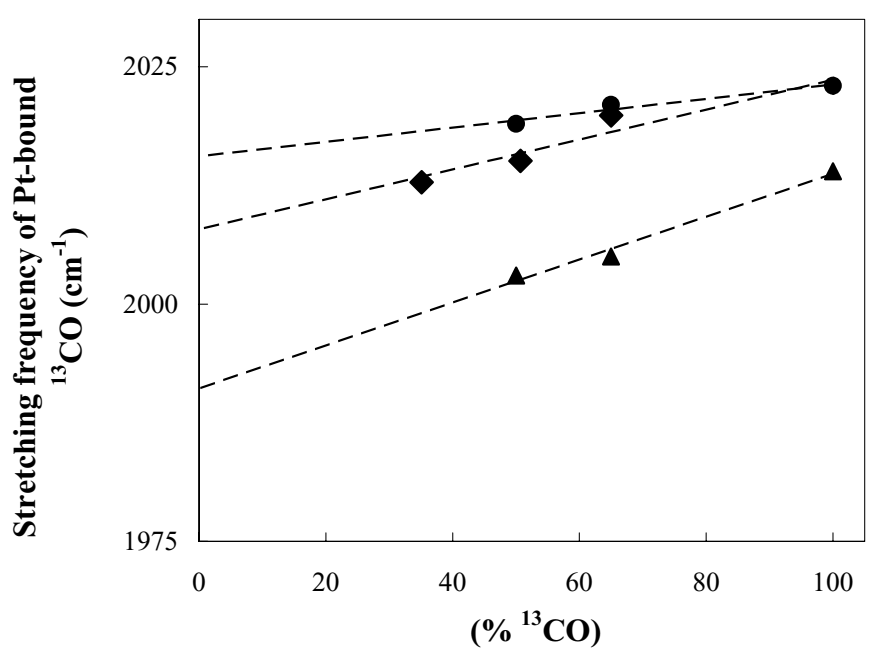

FIG. 9. RT stretching frequency of Pt-bound ${ }^{13} \mathrm{CO}$ adsorbed on different $\mathrm{Pt}$ and $\mathrm{Pt}-\mathrm{Au}$ catalysts as a function of the molar fraction of ${ }^{13} \mathrm{CO}$ in the ${ }^{12} \mathrm{CO} /{ }^{13} \mathrm{CO}$ mixture: $\diamond, 1 \mathrm{Pt} ; \boldsymbol{\bullet}, 1 \mathrm{Pt}-2 \mathrm{Au} ; \boldsymbol{\Delta}, 0.5 \mathrm{Pt}_{2} \mathrm{Au}_{4}$.

positions of ${ }^{13} \mathrm{CO}$ were thus extracted. Plots of the frequency of adsorbed ${ }^{13} \mathrm{CO}$ on $\mathrm{Pt}$ obtained from this deconvolution procedure versus the ${ }^{13} \mathrm{CO}$ mole fraction in the ${ }^{12} \mathrm{CO} /{ }^{13} \mathrm{CO}$ mixture for the three catalysts examined are shown in Fig. 9. Extrapolation to zero concentration of ${ }^{13} \mathrm{CO}$ in the gas phase yields the ${ }^{13} \mathrm{CO}$ singleton frequency at full coverage, eliminating the dipole-dipole interactions between neighboring adsorbate molecules. These frequencies are shown in Table 2. Similar values were obtained for 1Pt and 1Pt-2Au (2008 and $2014 \mathrm{~cm}^{-1}$, respectively), while a lower singleton frequency $\left(1990 \mathrm{~cm}^{-1}\right)$ was obtained for the cluster-derived $0.5 \mathrm{Pt}_{2} \mathrm{Au}_{4}$ sample, consistent with the results of the studies conducted at elevated temperatures. The combination of the two results suggests that in the case of the cluster-derived catalyst the electronic properties of $\mathrm{Pt}$ have been modified by the presence of $\mathrm{Au}$.

\subsection{Kinetic Results}

3.3.1. Selective catalytic reduction of NO by propylene. The NO reduction and propylene oxidation versus temperature curves for catalysts containing approximately $1 \mathrm{wt} \%$ $\mathrm{Pt}$ and for $2 \mathrm{wt} \% \mathrm{Au}$ loadings are shown in Fig. 10. Identical results were obtained with the $1 \mathrm{Pt}$ and $1 \mathrm{Pt}-2 \mathrm{Au}$ samples.

TABLE 2

Singleton Frequencies Obtained from ${ }^{12} \mathrm{CO} /{ }^{13} \mathrm{CO}$ Experiments

\begin{tabular}{cc}
\hline Catalyst sample & Singleton frequency $\left(\mathrm{cm}^{-1}\right)$ \\
\hline $1 \% \mathrm{Pt} / \mathrm{SiO}_{2}$ & 2008 \\
$0.8 \% \mathrm{Pt}-1.8 \% \mathrm{Au} / \mathrm{SiO}_{2}$ & 2014 \\
$0.4 \% \mathrm{Pt}_{2} \mathrm{Au}_{4} / \mathrm{SiO}_{2}$ & 1990 \\
\hline
\end{tabular}



FIG. 10. NO reduction and $\mathrm{C}_{3} \mathrm{H}_{6}$ oxidation vs. temperature over different $\mathrm{SiO}_{2}$-supported $\mathrm{Pt}$ and $\mathrm{Pt}-\mathrm{Au}$ catalysts: $\bigcirc, \boldsymbol{\bullet}, 1 \mathrm{Pt} ; \square, \mathbf{\square}, 1 \mathrm{Pt}-2 \mathrm{Au}$; $\triangle, \boldsymbol{\Lambda}, 0.5 \mathrm{Pt}_{2} \mathrm{Au}_{4} ; \diamond, \diamond, 2 \mathrm{Au}$. Open symbols: $\mathrm{C}_{3} \mathrm{H}_{6}$ oxidation; closed symbols: NO reduction (1000 ppm NO, $1000 \mathrm{ppm} \mathrm{C}_{3} \mathrm{H}_{6}, 1 \% \mathrm{O}_{2}$, balance $\mathrm{He}$, $\left.\mathrm{GHSV}=120,000 \mathrm{ml} \mathrm{h}^{-1} \mathrm{~g}^{-1}\right)$.

In both cases, the NO reduction and propylene oxidation curves closely match each other up to the temperature of maximum NO reduction. At higher temperatures, the reduction of NO decreases, while the propylene oxidation reaches $100 \%$ and remains constant at this level. The selectivity toward $\mathrm{N}_{2}$ in both cases ranges from 45 to $55 \%$, consistent with what was previously observed with similar catalysts $(26,27)$.

A significantly different behavior was observed for the cluster-derived catalyst $\left(0.5 \mathrm{Pt}_{2} \mathrm{Au}_{4}\right)$. In this case, a temperature delay of approximately $150^{\circ} \mathrm{C}$ was observed in both the NO reduction and propylene oxidation curves. In addition, a slight separation of the $\mathrm{C}_{3} \mathrm{H}_{6}$ oxidation and $\mathrm{NO}$ reduction curves was observed, with $\mathrm{C}_{3} \mathrm{H}_{6}$ oxidation preceding the NO reduction by approximately $10^{\circ} \mathrm{C}$. Furthermore, the selectivity toward $\mathrm{N}_{2}$ in this case was in the range of 70 to $80 \%$, which is significantly higher than what was observed with the previous samples. Finally, the monometallic 2Au catalyst prepared by impregnation showed no activity toward NO reduction and only minor oxidation activity at temperatures above $450^{\circ} \mathrm{C}$ under the conditions studied.

A similar behavior was also observed for the oxidation of propylene in the absence of NO. Results of these studies are shown in Fig. 11. Once again, the performance of $1 \mathrm{Pt}$ and $1 \mathrm{Pt}-2 \mathrm{Au}$ was very similar with only a minor temperature delay of approximately $10^{\circ} \mathrm{C}$ observed in the light-off curve of the $1 \mathrm{Pt}-2 \mathrm{Au}$ sample. A significant shift of $150^{\circ} \mathrm{C}$ toward higher temperatures was observed with the clusterderived catalyst, and the $2 \mathrm{Au}$ catalyst was only active at 


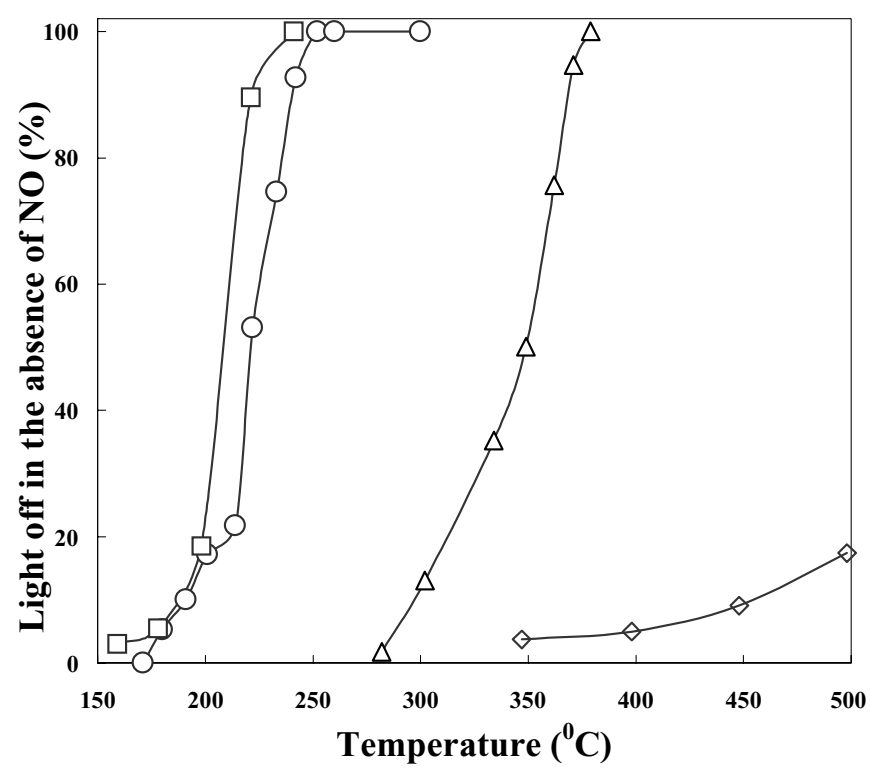

FIG. 11. $\mathrm{C}_{3} \mathrm{H}_{6}$ oxidation in the absence of $\mathrm{NO}$ vs. temperature over different $\mathrm{SiO}_{2}$-supported $\mathrm{Pt}$ and $\mathrm{Pt}-\mathrm{Au}$ catalysts: $\bigcirc, 1 \mathrm{Pt} ; \square, 1 \mathrm{Pt}-$ $2 \mathrm{Au} ; \triangle, 0.5 \mathrm{Pt}_{2} \mathrm{Au}_{4} ; \diamond, 2 \mathrm{Au}\left(1000 \mathrm{ppm} \mathrm{C}_{3} \mathrm{H}_{6}, 1 \% \mathrm{O}_{2}\right.$, balance $\mathrm{He}$, $\left.\mathrm{GHSV}=120,000 \mathrm{ml} \mathrm{h}^{-1} \mathrm{~g}^{-1}\right)$.

temperatures above $400^{\circ} \mathrm{C}$. These results are consistent with our previous mechanistic conclusions regarding the kinetic significance of the hydrocarbon activation during HC-SCR at temperatures below the temperature of maximum NO reduction (28). In fact, the light-off curves of Fig. 11 indicate that the observed shift in the NO reduction profile for the cluster-derived catalyst under HC-SCR conditions can be directly attributed to the lower propylene oxidation activity of this catalyst. In contrast, the presence of $\mathrm{Au}$ in the co-impregnated sample does not have such an effect.

Similar experiments were also conducted over a series of catalysts with a nominal Pt loading of $0.15 \mathrm{wt} \%$. As explained in the experimental section, the experiments in these cases were conducted at a proportionally lower space velocity $\left(20,000 \mathrm{ml} \mathrm{h}^{-1} \mathrm{~g}^{-1}\right)$ to facilitate comparisons among different catalyst samples. A small temperature delay (i.e., $20-25^{\circ} \mathrm{C}$ ) in both the $\mathrm{NO}$ reduction and $\mathrm{C}_{3} \mathrm{H}_{6}$ oxidation curves was observed with the co-impregnated $0.15 \mathrm{Pt}-0.3 \mathrm{Au}$ sample compared to the monometallic $0.15 \mathrm{Pt}$ sample at temperatures below the temperature of the maximum $\mathrm{NO}$ reduction (Fig. 12). The selectivity toward $\mathrm{N}_{2}$ was approximately $50 \%$, and the magnitude of the maximum NO reduction was comparable in both cases. Once again, the $0.075 \mathrm{Pt}_{2} \mathrm{Au}_{4}$ cluster-derived catalyst exhibited a significant shift toward higher temperatures in both the NO reduction and the $\mathrm{C}_{3} \mathrm{H}_{6}$ oxidation profiles. As with the $0.5 \mathrm{Pt}_{2} \mathrm{Au}_{4}$ cluster-derived sample, the selectivity toward $\mathrm{N}_{2}$ was also in the range of 70 to $80 \%$ in this case. A similar temperature shift was observed with the propylene oxidation in the absence of NO. Finally, we should point out that the results of kinetic studies conducted with a monometallic $0.15 \mathrm{Pt}$ catalyst prepared using an organometallic tert-butyl ligated Pt cluster (10) indicate that the catalytic behavior of this material is identical to that of the monometallic $1 \mathrm{Pt}$ sample.

Previous studies have led to the conclusion that the oxidation of hydrocarbons over $\mathrm{Pt}$ is a structure-sensitive reaction. Carballo and Wolf (29), for example, reported that propylene oxidation over alumina-supported Pt proceeds at a significantly lower rate on smaller Pt particles. In that study, differences of $10 \mathrm{~nm}$ in particle size (i.e., for 1 to $11 \mathrm{~nm}$ ) resulted in a ten-fold increase in the turnover frequency. Similar results were also reported by Garetto and Apesteguia for the oxidation of cyclopentane, methane, and benzene $(30,31)$. A similar Pt particle size effect has also been reported for the selective reduction of NO by hydrocarbons. Lower turnover frequencies over smaller Pt crystallites have been observed, for example, for the reduction of NO by either propylene $(32,33)$ or octane (34). Furthermore, previous attempts to promote the catalytic activity of $\mathrm{Pt}$ for the selective catalytic reduction of NO by propylene by the addition of $\mathrm{Au}$ appear at first to have had contradictory results. Bimetallic $\mathrm{Pt}-\mathrm{Au}$ catalysts prepared by incipient wetness impregnation from individual metal salts (35) or by redox techniques (36) have similar activity with the monometallic Pt only catalysts, in agreement with the results of this study. In contrast, reports from the patent

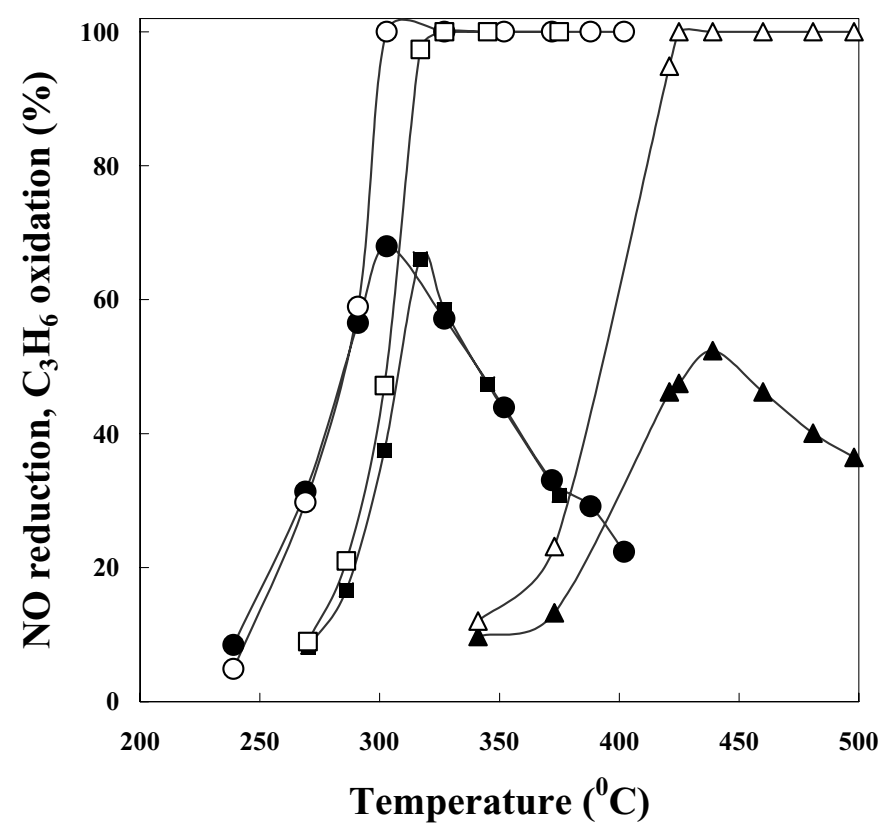

FIG. 12. NO reduction and $\mathrm{C}_{3} \mathrm{H}_{6}$ oxidation vs. temperature over different $\mathrm{SiO}_{2}$-supported Pt and Pt-Au catalysts: $\bigcirc, \boldsymbol{\bullet}, 0.15 \mathrm{Pt} ; \square, \mathbf{\square}, 0.15 \mathrm{Pt}-$ $0.3 \mathrm{Au} ; \triangle, \boldsymbol{\Delta}, 0.075 \mathrm{Pt}_{2} \mathrm{Au}_{4}$; open symbols: $\mathrm{C}_{3} \mathrm{H}_{6}$ oxidation; closed symbols: NO reduction (1000 ppm NO, $1000 \mathrm{ppm} \mathrm{C}_{3} \mathrm{H}_{6}, 1 \% \mathrm{O}_{2}$, balance $\mathrm{He}$, $\left.\mathrm{GHSV}=20,000 \mathrm{ml} \mathrm{h}^{-1} \mathrm{~g}^{-1}\right)$. 


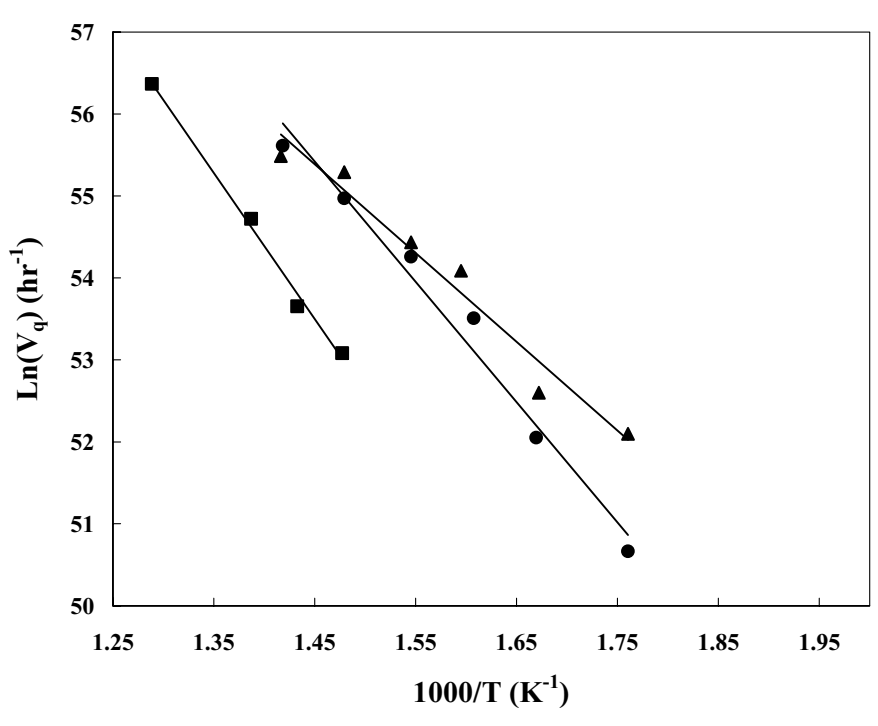

FIG. 13. Arrhenius plot for the ${ }^{16} \mathrm{O} /{ }^{18} \mathrm{O}$ homoexchange reaction: $1 \mathrm{Pt} ; \bullet, 1 \mathrm{Pt}-2 \mathrm{Au} ; \mathbf{\square}, 0.5 \mathrm{Pt}_{2} \mathrm{Au}_{4}$.

literature indicate a promoting effect when the $\mathrm{Au}$ was added by ion exchange or deposition methods (37).

In light of these reports, the results obtained in our study suggest the possibility of similar Pt particle or ensemble (in the case of the bimetallic catalysts) sizes for the monometallic $\mathrm{Pt} / \mathrm{SiO}_{2}$ and the co-impregnated $\mathrm{Pt}-\mathrm{Au} / \mathrm{SiO}_{2}$ samples, and a significantly smaller $\mathrm{Pt}$ particle or ensemble size for the cluster-derived $\mathrm{Pt}_{2} \mathrm{Au}_{4} / \mathrm{SiO}_{2}$ catalysts.

3.3.2. ${ }^{16} \mathrm{O} /{ }^{18} \mathrm{O}$ exchange reaction. Arrhenius plots (utilizing TOFs) for the ${ }^{16} \mathrm{O} /{ }^{18} \mathrm{O}$ exchange reaction over $1 \mathrm{Pt}$, $1 \mathrm{Pt}-2 \mathrm{Au}$, and $0.5 \mathrm{Pt}_{2} \mathrm{Au}_{4}$ catalysts are shown in Fig. 13. The results indicate that the cluster-derived $0.5 \mathrm{Pt}_{2} \mathrm{Au}_{4}$ sample is less active for the homoexchange reaction than the $1 \mathrm{Pt}$ or the $1 \mathrm{Pt}-2 \mathrm{Au}$ catalysts. The $1 \mathrm{Pt}$ and $1 \mathrm{Pt}-2 \mathrm{Au}$ samples exhibited similar activities. Finally, the $2 \mathrm{Au}$ sample was found to be completely inactive for this reaction, consistent with the idea that oxygen cannot be activated by gold. Apparent activation energies for the ${ }^{16} \mathrm{O} /{ }^{18} \mathrm{O}$ exchange reaction were calculated for the different samples from the slopes of the respective curves and the results are summarized in Table 3. A significantly higher apparent activation energy was observed over the cluster-derived sample.

\section{TABLE 3}

Apparent Activation Energy for the ${ }^{16} \mathrm{O} /{ }^{18} \mathrm{O}$ Homoexchange Reaction over Different $\mathrm{SiO}_{2}$-Supported $\mathrm{Pt}$ and $\mathrm{Pt}-\mathrm{Au}$ Samples

\begin{tabular}{cc}
\hline Catalyst sample & $E_{\mathrm{a}}(\mathrm{kJ} / \mathrm{mol})$ \\
\hline $1 \mathrm{Pt}$ & 90 \\
$1 \mathrm{Pt}-2 \mathrm{Au}$ & 122 \\
$0.5 \mathrm{Pt}_{2} \mathrm{Au}_{4}$ & 148 \\
\hline
\end{tabular}

It was previously shown that the ${ }^{16} \mathrm{O} /{ }^{18} \mathrm{O}$ homoexchange reaction over supported $\mathrm{Pt}$ catalysts is a structure-sensitive reaction favored over larger Pt particles or ensembles (3840). In light of this previous work, our results suggest that in the case of the cluster-derived $0.5 \mathrm{Pt}_{2} \mathrm{Au}_{4}$ catalyst the $\mathrm{Pt}$ ensembles are smaller than in the case of the $1 \mathrm{Pt}$ or the $1 \mathrm{Pt}-2 \mathrm{Au}$ samples prepared by impregnation. The 1Pt and $1 \mathrm{Pt}-2 \mathrm{Au}$ samples appear to have similar Pt particle or ensemble sizes. From this point of view, the results from the ${ }^{16} \mathrm{O} /{ }^{18} \mathrm{O}$ exchange reaction are in complete agreement with the results of the selective catalytic reduction of NO by propylene described in the previous section.

\section{DISCUSSION}

Kinetic results obtained for the selective catalytic reduction of NO by propylene, the oxidation of propylene in the absence of $\mathrm{NO}$, and the ${ }^{16} \mathrm{O} /{ }^{18} \mathrm{O}$ homoexchange reaction indicate significant differences in the behavior of the various $\mathrm{SiO}_{2}$-supported $\mathrm{Pt}$ and $\mathrm{Pt}-\mathrm{Au}$ catalysts examined in this study. In particular, the cluster-derived $0.5 \mathrm{Pt}_{2} \mathrm{Au}_{4}$ catalyst shows a significantly lower activity for all three reactions, which is manifested in the case of the HC-SCR and the propylene oxidation as a shift of the conversiontemperature curves toward higher temperatures. In addition, a higher selectivity for $\mathrm{N}_{2}$ is observed with this catalyst during HC-SCR. In contrast, the $1 \mathrm{Pt}-2 \mathrm{Au}$ catalyst prepared by co-impregnation from individual precursors of $\mathrm{Pt}$ and $\mathrm{Au}$ exhibits behavior which is almost identical to that of the monometallic 1Pt catalyst. Corroborated with the fact that the monometallic $2 \mathrm{Au}$ catalyst prepared by impregnation is inactive for all three reactions, these results demonstrate that while $\mathrm{Pt}$ and Au do not affect each other in the $1 \mathrm{Pt}-2 \mathrm{Au}$ system, the presence of Au has a strong effect on the catalytic behavior of $\mathrm{Pt}$ in the cluster-derived $0.5 \mathrm{Pt}_{2} \mathrm{Au}_{4}$ catalyst.

During the presentation of the results it was indicated that both the oxidation of hydrocarbons and the ${ }^{16} \mathrm{O} /{ }^{18} \mathrm{O}$ homoexchange reactions are known to be structure sensitive over supported platinum catalysts. In fact, the origin of the structure sensitivity is the same in both cases and is associated with the higher rate of the activation of molecular oxygen over larger Pt ensembles. Our previous work in the HC-SCR area has concluded that the activation of propylene by molecular oxygen is the rate-determining step of this reaction at temperatures below the temperature of maximum NO conversion $(28,41)$. Consequently, it is not surprising for HC-SCR to exhibit the same type of structure sensitivity as well. In fact, there are published literature reports that have experimentally demonstrated such a structured sensitivity effect over supported Pt catalysts with different Pt particle sizes $(33,34)$. Hence, in light of these reports, it is reasonable to attempt to attribute the differences in the kinetic results obtained in this study to 
differences in $\mathrm{Pt}$ ensemble sizes and, in particular, to a smaller Pt ensemble size in the case of the cluster-derived $0.5 \mathrm{Pt}_{2} \mathrm{Au}_{4}$ catalyst.

Indeed, the results of the TEM and hydrogen chemisorption measurements suggest that the cluster-derived catalyst has a slightly smaller metal particle size (on the order of $1 \mathrm{~nm}$ ) and a higher Pt dispersion than either the monometallic $1 \mathrm{Pt}$ or the co-impregnated $1 \mathrm{Pt}-2 \mathrm{Au}$ systems. However, given the magnitude of the structure sensitivity effects reported previously for the reactions examined (33, $34,39,40)$, it becomes clear that these differences in metal particle size are not sufficient to justify the observed differences in catalytic behavior. As mentioned in the previous paragraph, the kinetic results suggest that the active $\mathrm{Pt}$ ensemble size in the cluster-derived $0.5 \mathrm{Pt}_{2} \mathrm{Au}_{4}$ catalyst is significantly smaller than the active Pt ensemble size in the monometallic $1 \mathrm{Pt}$ and the co-impregnated $1 \mathrm{Pt}-2 \mathrm{Au}$ systems. Since identical kinetic results were obtained with the monometallic Pt catalysts irrespective of the precursor used (salt-derived or cluster-derived) as was discussed in section 3.3.1, the smaller Pt ensemble sizes in the former case can be attributed to the presence of $\mathrm{Au}$. In turn, this can be interpreted as the first indication of the formation of $\mathrm{Pt}-\mathrm{Au}$ bimetallic particles in the $0.5 \mathrm{Pt}_{2} \mathrm{Au}_{4}$ catalyst. The presence of $\mathrm{Au}$ in the surface of such particles is expected to "break down" large Pt ensembles and result in an average Pt ensemble size, which is significantly smaller than the average metal particle size. In addition, it is possible that the presence of $\mathrm{Au}$ in such bimetallic particles also results in a modification of the electronic, and hence catalytic, properties of $\mathrm{Pt}$.

Further evidence for the formation of $\mathrm{Pt}-\mathrm{Au}$ bimetallic particles in the $0.5 \mathrm{Pt}_{2} \mathrm{Au}_{4}$ catalyst can be found in the results of the $\mathrm{CO}$ adsorption experiments conducted in this study. The FTIR spectra of this catalyst collected at room temperature and full $\mathrm{CO}$ coverage indicate the presence of a new Au-bound weakly adsorbed surface $\mathrm{CO}$ species and a red shift in the frequency of the Pt-bound CO. Previous literature reports indicate that only finely dispersed $\mathrm{Au}$ crystallites lower than $5 \mathrm{~nm}$ in diameter can adsorb $\mathrm{CO}$. Therefore, the FTIR results suggest that $\mathrm{Au}$ is finely dispersed in this sample. The red shift observed in the same FTIR spectra in the frequency of the Pt-bound CO can be associated with either a geometric or an electronic effect. In the first case, the geometric ("dilution") effect is the result of $\mathrm{Au}$ breaking up the large Pt ensembles, thus creating a weaker lateral interaction between adsorbed $\mathrm{CO}$ molecules (i.e., decreased dipole-dipole coupling in the adlayer). In the second case, electronic donation from one metal to the other can increase the back donation in the $2 \pi^{*}$ antibonding orbitals of adsorbed $\mathrm{CO}$ molecules, and consequently cause the observed red shift. The estimation of the singleton frequency (i.e., the frequency of a single $\mathrm{CO}$ molecule adsorbed on one metal site) can help to dis- cern between dipole-dipole coupling shifts and shifts due to changes in the electronic state of the surface metal site. Such estimates were obtained by two different approaches: surface equilibration with gas-phase $\mathrm{CO}$ at elevated temperatures (i.e., equilibrated low surface coverages of $\mathrm{CO}$ ) and use of ${ }^{12} \mathrm{CO} /{ }^{13} \mathrm{CO}$ mixtures at full coverage. Although at first it appears that both approaches provide the same result, in reality two different values of the singleton frequency can be obtained. The high-temperature experiments reveal the frequency of a single $\mathrm{CO}$ molecule adsorbed on a practically empty surface, while the experiments utilizing mixtures of the two isotopes reveal the frequency of an uncoupled ${ }^{12} \mathrm{CO}$ (or ${ }^{13} \mathrm{CO}$ ) molecule adsorbed on a surface saturated with ${ }^{13} \mathrm{CO}$ (or ${ }^{12} \mathrm{CO}$ ) molecules.

The important point from the perspective of this paper is that both approaches demonstrated differences of about $15-20 \mathrm{~cm}^{-1}$ in the singleton frequency of adsorbed $\mathrm{CO}$ on the cluster-derived $0.5 \mathrm{Pt}_{2} \mathrm{Au}_{4}$ catalyst, compared to the monometallic $1 \mathrm{Pt}$ catalyst or the $1 \mathrm{Pt}-2 \mathrm{Au}$ catalyst prepared by co-impregnation from individual precursors of $\mathrm{Pt}$ and $\mathrm{Au}$. These differences are a clear indication that in the cluster-derived catalyst not only the Pt ensemble size has been affected, but also the electronic properties of $\mathrm{Pt}$ have been modified by the presence of Au. Hence, the combination of kinetic and spectroscopic evidence leads to the conclusion that in the cluster-derived catalyst $\mathrm{Pt}$ and $\mathrm{Au}$ are intimately mixed in the form of bimetallic $\mathrm{Pt}-\mathrm{Au}$ particles. These particles are much larger than the original six metal atom clusters and, therefore, agglomeration is taking place during the ligand-removal process. However, it appears that during this agglomeration no significant segregation of $\mathrm{Pt}$ and $\mathrm{Au}$ takes place.

The formation of bimetallic particles is greatly dependent on the precursors used. In contrast to the cluster-derived catalyst, the $1 \mathrm{Pt}-2 \mathrm{Au}$ catalyst prepared by co-impregnation from individual precursors of $\mathrm{Pt}$ and Au exhibits both catalytic and spectroscopic properties that are very similar to those of the monometallic $1 \mathrm{Pt}$ sample. This material appears to follow a model in which $\mathrm{Pt}$ and Au are segregated, which would be expected based on the miscibility gap between the two metals. Furthermore, Au in this material appears to be in the form of larger crystallites since the FTIR studies did not reveal any $\mathrm{CO}$ adsorption. In fact, it is reasonable to assume that the majority of $\mathrm{Au}$ is in the form of the larger particles observed in the tail end of the metal particle size distribution of this catalyst (Fig. 1).

Finally, we should point out that although the use of the organometallic $\mathrm{Pt}-\mathrm{Au}$ cluster precursors appears to prevent the segregation of the two metals into separate particles, metal mobility within these particles and the subsequent surface-enrichment effect cannot be ruled out. Thermodynamic arguments indicate that the surface of the bimetallic particles is expected to be enriched with the element having the lowest surface tension. In the $\mathrm{Pt}-\mathrm{Au}$ pair, $\mathrm{Au}$ exhibits 
the lowest surface tension and therefore a Au enrichment of the surface is possible. However, a lower hydrogen uptake would be expected if the surface was enriched in $\mathrm{Au}$, and no such trend was observed in the data of Table 1. This may be due to the nanoscale dimension of the bimetallic particles involved in this study. At this scale, metal behavior may differ significantly from "bulk" behavior observed with larger particles.

\section{CONCLUSIONS}

The use of an acetylide-ligated organometallic $\mathrm{Pt}-\mathrm{Au}$ cluster as a precursor has led to the synthesis of supported $\mathrm{Pt}-\mathrm{Au}$ catalysts containing bimetallic $\mathrm{Pt}-\mathrm{Au}$ particles. In contrast, a conventional synthesis approach utilizing incipient wetness impregnation of individual $\mathrm{Pt}$ and $\mathrm{Au}$ precursors results in catalysts containing segregated $\mathrm{Pt}$ and $\mathrm{Au}$ catalysts. Catalysts prepared using the cluster route exhibited significantly different catalytic behavior for a series of test reactions, in addition to different adsorption properties for $\mathrm{CO}$. These differences are the result of the presence of finely dispersed $\mathrm{Au}$, smaller Pt ensembles, and modification of the electronic properties of $\mathrm{Pt}$ by $\mathrm{Au}$ in the $\mathrm{Pt}-\mathrm{Au}$ bimetallic particles. These particles appear to be fairly stable and retain their properties and composition even after prolonged exposure to HC-SCR conditions (i.e., oxidative atmosphere and temperatures up to $500^{\circ} \mathrm{C}$ ).

\section{ACKNOWLEDGMENTS}

The authors express their gratitude to the U.S. Department of Energy (DE-FG02-96ER14666) for financial support of this work. M. D. A. also acknowledges support from an international supplement from the National Science Foundation (CTS-9624433). Finally, Bert D. Chandler is acknowledged for the preparation of the organometallic clusters used as precursors and for his useful suggestions during this work.

\section{REFERENCES}

1. Bouwman, R., and Sachtler, W. H. M., J. Catal. 19, 127 (1970).

2. Sachdev, A., and Schwank, J., J. Catal. 120, 353 (1989).

3. Gates, B. C., Chem. Rev. 95, 511 (1995).

4. Psaro, R., and Recchia, S., Catal. Today 41, 139 (1998).

5. Graf, I. V. G., Bacon, J. W., Curley, M. E., Ito, L. N., and Pignolet, L. H., Inorg. Chem. 35, 689 (1996).

6. Chandler, B. D., Rubinstein, L. I., and Pignolet, L. H., J. Mol. Catal. 133, 267 (1998).

7. Chandler, B. D., Schabel, A. B., Blanford, F., and Pignolet, L. H., J. Catal. 187, 367 (1999).
8. Chandler, B. D., and Pignolet, L. H., Catal. Today 65, 39 (2001).

9. Chandler, B. D., Schabel, A. B., and Pignolet, L. H., J. Phys. Chem. B 105, 149 (2001).

10. Chandler, B. D., Ph.D. dissertation, University of Minnesota, Minneapolis, 1999.

11. Espinet, P., Fornies, J., Martinez, F., Tomas, M., Lalinde, E., Moreno, M. T., Ruiz, A., and Welch, A. J., J. Chem. Soc., Dalton Trans. 791 (1990).

12. Martin, D., and Duprez, D., J. Phys. Chem. 100, 9429 (1996).

13. Balakrishnan, K., Sachdev, A., and Schwank, J., J. Catal. 121, 441 (1990).

14. Schwank, J., Balakrishnan, K., Sachdev, A., Volter, J., Ryczkowski, J., Figueras, F., Grunert, W., Menon, P. G., Clarke, J. K. A., Coenen, J., and Paffett, M., Stud. Surf. Sci. Catal. 75, 905 (1993).

15. Yates, D. J. C., J. Colloid Interface Sci. 29, 194 (1969).

16. Boccuzzi, F., Guglielminotti, E., Pinna, F., and Strukul, G., Surf. Sci. 377, 728 (1997).

17. Liu, H., Kozlov, A. I., Kozlova, A. P., Shido, T., Asakura, K., and Iwasawa, Y., J. Catal. 185, 252 (1999).

18. Conrad, H., Ertl, G., and Kuppers, J., Surf. Sci. 76, 323 (1978).

19. Delacruz, C., and Sheppard, N., Spectrochim. Acta Part A 50, 271 (1994).

20. Podkolzin, S. G., Shen, J., de Pablo, J. J., and Dumesic, J. A., J. Phys. Chem. B 104, 4169 (2000).

21. France, J., and Hollins, P., J. Electron Spectrosc. Relat. Phenom. 64/65, 251 (1993).

22. Schubert, M. M., Kahlich, M. J., Gasteiger, H. A., and Behm, R. J., J. Power Sources 84, 175 (1999).

23. Boccuzzi, F., Chiorino, A., Tsubota, S., and Haruta, M., J. Phys. Chem. 100, 3625 (1996).

24. Crossley, A., and King, D. A., Surf. Sci. 95, 131 (1980).

25. Toolenaar, F. J. C., Stoop, F., and Ponec, V., J. Catal. 82, 1 (1983).

26. Roberts, K. L., and Amiridis, M. D., Ind. Eng. Chem. Res. 36, 3528 (1997).

27. Captain, D. K., Roberts, K. L., and Amiridis, M. D., Catal. Today 42, 93 (1998).

28. Captain, D. K., Mihut, C., Dumesic, J. A., and Amiridis, M. D., Catal. Lett., submitted for publication.

29. Carballo, L. M., and Wolf, E. E., J. Catal. 53, 366 (1978).

30. Garetto, T. F., and Apesteguia, C. R., Catal. Today 62, 189 (2000).

31. Garetto, T. F., and Apesteguia, C. R., Appl. Catal. B 32, 83 (2000).

32. Lee, J.-H., and Kung, H. H., Catal. Lett. 51, 1 (1998).

33. Denton, P., Giroir-Fendler, A., Praliaud, H., and Primet, M., J. Catal. 189, 410 (2000).

34. Burch, R., Fornasiero, P., and Southward, B. W. L., Chem. Commun. 625 (1998).

35. Burch, R., and Watling, T. C., Appl. Catal. B 11, 207 (1997).

36. Demichelli, M. C., Hoang, L. C., Menezo, J. C., Barbier, J., and Pinabiau-Carlier, M., Appl. Catal. A 97, L11 (1993).

37. Nakatsuji, T., EP 0602602 A1 (1993).

38. Taha, R., and Duprez, D., J. Chim. Phys. 92, 1506 (1995).

39. Duprez, D., Stud. Surf. Sci. Catal. 112, 13 (1997).

40. Descorme, C., and Duprez, D., Appl. Catal. A 202, 231 (2000).

41. Captain, D. K., and Amiridis, M. D., J. Catal. 194, 222 (2000). 